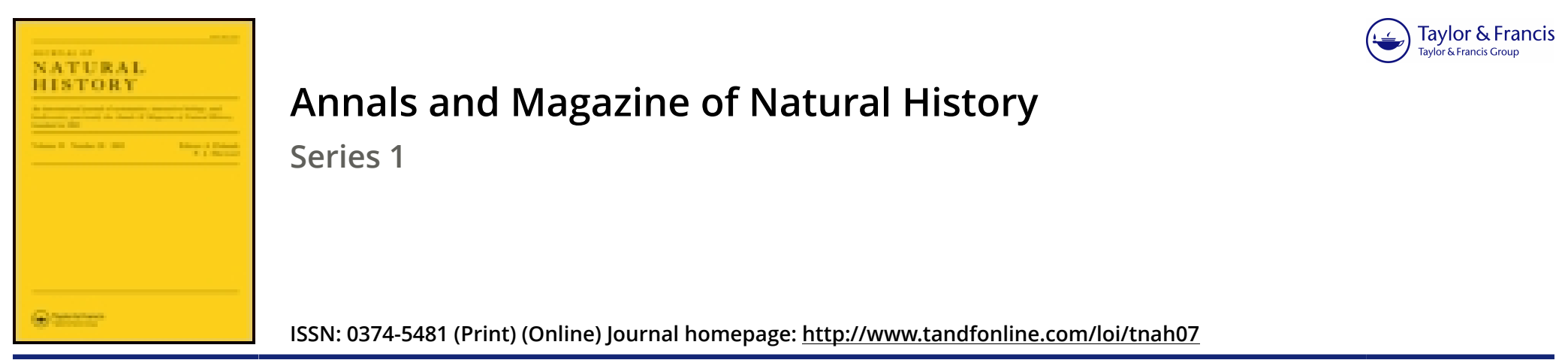

\title{
Alsine stricta, Wahl
}

\section{C.C.B.}

To cite this article: C.C.B. (1844) Alsine stricta, Wahl, Annals and Magazine of Natural History, 14:91, 309-310, DOI: 10.1080/037454809495177

To link to this article: http://dx.doi.org/10.1080/037454809495177

册Published online: 23 Dec 2009.

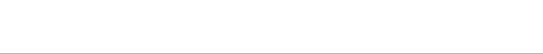

Submit your article to this journal $\widetilde{ }$

Q View related articles $\sqsubset$ 
five fathoms piercing, and partially imbedded in, the Avicula margaritifera); Cuming.

This peculiarly shaped shell exhibits the same kind of delicate marginal frill of laminæ as the well-known Cypricardia coralliophaga, and belongs to a mollusk of the same terebrating habits. 'The shells of terebrating mollusks vary so exceedingly in form, according to circumstances of situation, \&c., that were the $C$. laminala not entirely destitute of the fine radiating striæ which characterise the C. coralliophaga, it might be regarded as a modification of that species.

Cypricardia obesa. Cypr.testd subquadrato-ovata, valdè gibbosa, tumidd, latere postico subobliquè angulato ; longitudinaliter striata, striis profundè incisis; lutescente-alba.

Conch. Icon., Cypricardia, pl. 2. f. 10.

Cypricardia Solenoldes. Cypr. testa angustata, Soleniformi, latere postico plano-angulalo; alba, posticè purpureo-fusco obsoletè radiatd; umbonibus purpureo-fuscis ; intus alba, ad extremitatem posticam purpureo-violaceo tincta.

Conch. Icon., Cypricardia, pl. 2. f. 11.

Hab. Calbayog, island of Samar, Philippines (found piercing soft slaty rocks; low water); Cuming.

The Cypricardia Solenoides, though approximating greatly in form to the Cypricardia coralliophaga, differs materially in structure and composition; the two species indeed exhibit all the differences upon which De Blainville founded his genus Coralliophaga. Instead of presenting that pellucid tenuity which seems peculiar to the terebrating species, it is of the same solid opake structure as the Cypricardia vellicata, the umbones have the same purplish-brown patch upon them, and there is an evident indication of the same posterior streaks of that colour.

\section{MISCELLANEOUS.}

CIRSIUM SETOSUM, M. BIEB.

Ters plant has recently been found by Dr. Dewar of Dunfermline on the shore of the Firth of Forth near Culross, in considerable quantity. It has probably been introduced from Odessa with merchandise, but is now quite established in Scotland. It is very satisfactory to me to learn that Sir W. Hooker, who possesses authentic specimens of M. Bieberstein's plant, has come to the same conclusion which I had done concerning the identity of the plant gathered by Dr. Dewar and that described in the 'Flora 'Tauro-Caucasica.'C. C. B.

\section{ALSINE STRICTA, WAHL.}

A few weeks since, my friend Mr. Jas. Backhouse, jun. of York kindly sent me a specimen of $A$. stricta, which had been just discovered on Widdy Bank Fell, on the Durham side of the upper part of Teesdale, by a party of botanists, consisting of Messrs. John Tatham, jun. of Settle, G. S. Gibson of Saffron Walden, S. Thompson, and Jas. Backhouse, sen. and jun. of York. Growing in so utterly wild 
a country, and being a native of Germany and the northern parts of Europe, it must be considered as one of the most interesting additions that has been recently made to our native flora.-C. C. B.

TEGUMENTS OF GASTEROPOD MOLLUSCA.

Among the kinds of covering of Gasteropod Mollusca, no solid bodies have been noticed but such as are known under the name of Shells. In two genera near to Doris, all the fleshy part of the body is strewed in every direction with calcareous spiculæ. In one of them, these spiculæ stick out in such a manner that the animal has its body all bristled with prickles. Similar spiculæ have been met with in the mantle of a young Bulla. At a time when, thanks to the labours of Ehrenberg, the study of microscopic fossils has made an unexpected stride, these facts may be of some value in guarding zoologists against referring to Infusoria the remains of animals belonging to a much higher group.-Comptes Rendus, July 15, 1844.

NEST OF THE DINORNIS.

Description by Captains Cook and Flinders of Birds ${ }^{3}$ Nests of enormous size on the coast of New Holland; by Prof. Edwand Hiтchсock, Dec. 22,1843 .

In lecturing on the huge footmarks of sandstone in the Connecticut valley, I have been in the habit for many years of reading to my classes, as the poetry of the subject, some statements from the twelfth volume of the 'Athenæum, or Spirit of the English Magazines' (p. 48), respecting enormously large birds and birds' nests. As some of these statements are manifestly fabulous, it never occurred to me till today to inquire whether any of them were true. I was led to make the inquiry probably by the astonishing discoveries of Prof. Owen respecting the danger bird of New Zealand; and the result is, that I have almost persuaded myself, that with the help of Captains Cook and Flinders $I$ have found the nest of the Dinornis on the coast of New Holland. These navigators have given the following statements in their published voyages. I quote Cook's account from Kerr's 'Collection of Voyages and Travels,' vol. xiii. p. 318 . It was Cook's first voyage. Lizard Island is near the north-east coast of New Holland, not far from Cape Flattery, and in about $15^{\circ} \mathrm{S}$. lat.

"At two in the aftermoon," says Cook, "there being no hope of clear weather, we set out from Lizard Island to return to the ship, and in our way landed upon the low sandy island with trees upon it which we had remarked in our going out. Upon this island we saw an incredible number of birds, chiefly sea-fowl; we found also the nest of an eagle with young ones, which we killed; and the nest of some other bird, we knew not what, of a most enormous size. It was built with sticks upon the ground, and was no less than six and twenty feet in circumference, and two feet eight inches high. To this spot we gave the name of Eagle Island," \&c.

Capt. Flinders found two similar nests on the south coast of New Holland in King George's Bay. Not having his work at hand, I quote from the 'Quarterly Review' for October 1814 his description of these nests :- 